\title{
Intraocular pressure menagement with transpalpebral tonometry
}

\section{Transpalpebral tonometri ile göz içi basıncı ölçülmesi}

\author{
Mustafa IIlker Toker, Ayhan Dursun*
}

Department of Ophthalmology (Assoc. Prof. M. İ. Toker, MD., Assist. Prof. A. Dursun, MD.), Cumhuriyet University School of Medicine, TR-58140 Sivas

\begin{abstract}
Applanation tonometry is the method of measuring intraocular pressure (IOP) with instruments the corneal surface. The Goldmann applanation tonometer (GAT) is regarded as the "gold standard" of measuring IOP. An irregular and opaque corneal surface compromises IOP measurement by Goldmann applanation tonometry. In such cases accurate measurement without corneal contact would be applicable. The transpalpebral tonometer is new method and measures IOP without corneal contact through the eyelid.
\end{abstract}

Keywords: İntraocular pressure, transpalpebral tonometry

\section{Özet}

Applanasyon tonometrisi kornea yüzeyinden aletler kullanılarak göz içi basıncı ölçen bir yöntemdir. Goldman applanasyon tonometrisi göz içi basınç ölçümünde altın standart olarak görülmektedir. Düzensiz ve opak kornealarda Goldman applanasyon tonometrisi ile göz içi basınç ölçümü güçleşmektedir. Bu gibi durumlarda korneaya temas olmadan ölçüm yapmak daha uygun olacaktır. Transpalpebral tonometri korneal temas olmadan göz kapağı üzerinden göz içi basıncı ölçen yeni bir metoddur.

Anahtar sözcükler: Göz içi basıncı, transpalpebral tonometri

Geliş tarihi/Received: August 02, 2012; Kabul tarihi/Accepted: November 07, 2012

\section{*Corresponding author:}

Dr. Ayhan Dursun, Göz Hastalıkları Anabilim Dalı, Cumhuriyet Üniversitesi Tıp Fakültesi TR58140 Sivas. E-mail: ayhan_dursun@mynet.com.tr

\section{Introduction}

Glaucoma is a neurodegenerative disease that may causes legal blindness worldwide. The assessment of intraocular pressure (IOP) could lead to significantly earlier diagnosis of glaucoma patients. Elevated intraocular pressure is the only controllable risk factor [1]. Thus evaluation of intraocular pressure is very important in glaucoma patients.

The Diaton tonometer is a portable, transpalpebral tonometry device, and measures the IOP without contact with the cornea, fluorescein staining and local anesthesia (Figure 1.) It is an improved version of the TGDc-01 tonometer. The acoustic sensor of vertical position and new software of automatic intraocular pressure average value evaluation from a series of measurements are introduced into the Diaton tonometer as updates from TGDc-01. Additionally, the tonometer tip of Diaton is to be placed as close to the ciliary edge as possible $[2,3]$. 


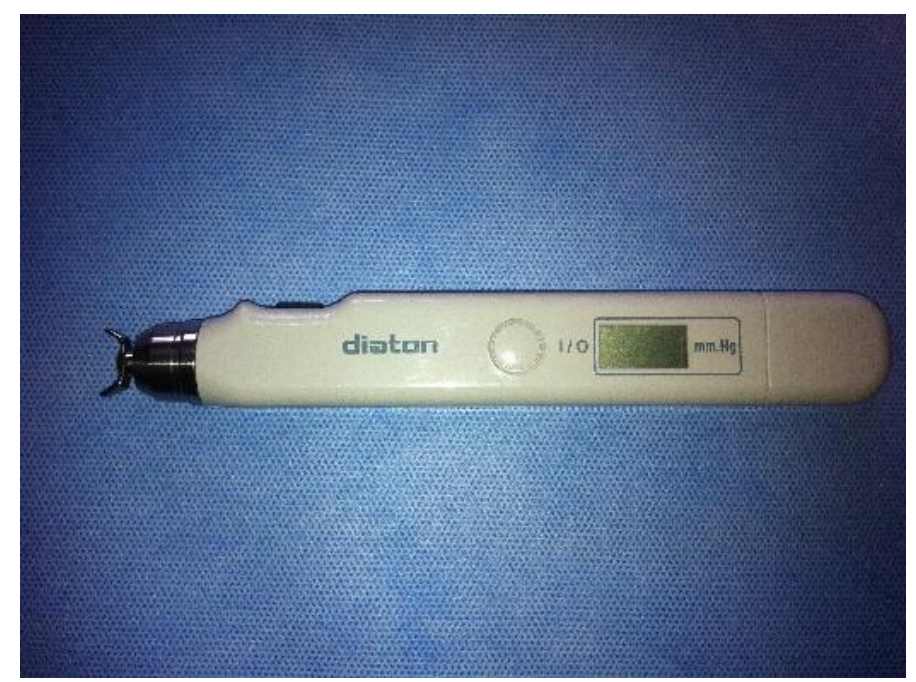

Figure 1. The transpalpebral tonometer Diaton.

The transpalpebral tonometer may be effective in the presence of conjunctival or corneal disease, following corneal surgery, in bedridden patients, in children and in contact lenswears [2]. The patient is in a recumbent position, with the glance line being oriented at an angle of approximately $45^{\circ}$ to the horizontal. The observer stands behind the patient and pulls up the upper eyelid with his/her free hand, so that the lidmargin can touch the limbus, and places the tonometer's tip perpendicular onto the cartilaginous part of the eyelid, where it is about $2 \mathrm{~mm}$ behind the lid margin of the upper eyelid; the tip should be parallel to the lid margin. When the tip of the tonometer touches the eyelid, the measurement (falling of the rod) automatically starts (Figure 2). This kind of tonometer is easy to use and cause no pain to patients [4-6].

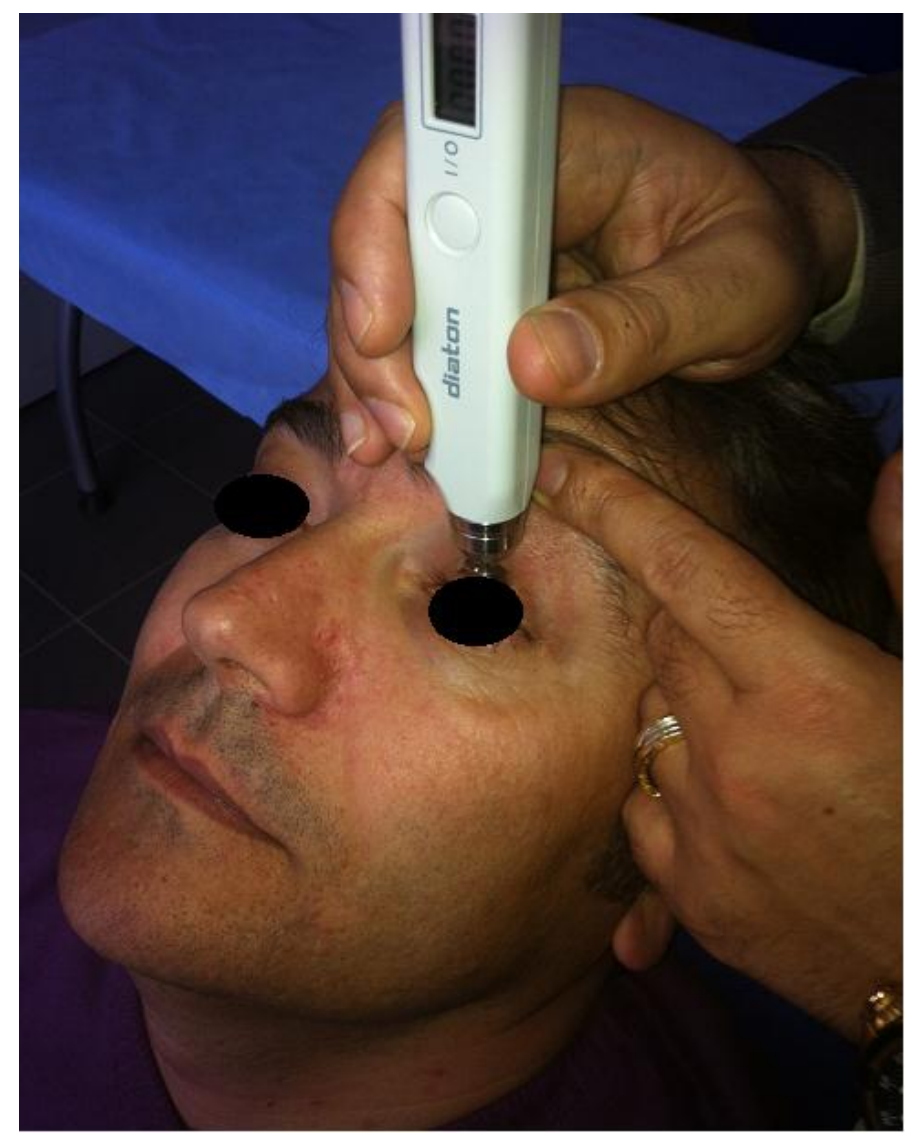

Figure 2. Diaton tonometer in use with the patient in sitting position. 
In our recent study, we aimed to examine the effects of central corneal thickness on the measures obtained from transpalpebral tonometry (Diaton), and to identify correlations between intraocular pressure (IOP) measurements with Diaton and the Goldmann applanation tonometer (GAT), we have shown that the mean Diaton tonometer readings were lower than C-GAT measurements Furthermore, the Diaton measurements show moderate correlation with those provided by applanation tonometry and Diaton tonometer seems to be more affected by the corneal thickness, especially in the thinnest corneas [3]. In another study by Doherty et al. [2] two hundred and fifty right eyes underwent both Goldmann applanation tonometry and Diaton tonometry. Mean intraocular pressure was $13.8 \pm 3.6 \mathrm{mmHg}$ using Goldmann applanation tonometry and $13.2 \pm 4.3 \mathrm{mmHg}$ using the transpalpebral tonometry. Upper and lower limits of agreement were $+8.4 \mathrm{mmHg}$ and $9.6 \mathrm{mmHg}$, respectively. The transpalpebral measurements show poor agreement with those provided by Goldmann applanation tonometry. Other possible causes of errors are as follows: deviation of the Diaton tonometer from the exact vertical position [1], physical or pathological alteration of scleral rigidity and elasticity [4], the exact location of the tonometer tip [7], and/or central cornea and lid thicknesses [3].

In summary the transpalpebral tonometer is a portable, lightweight device wich measures intraocular pressure (IOP) through the upper eyelid. The IOP measurements obtained with the transpalpebral tonomater generally correlate moderate to poor with those offered by Goldmann applanation tonometry. Therefore the transpalpebral tonometer seems to be a better choice for tonometry in patients with in awake children than palpation of intra ocular pressure. The transpalpebral tonometer might be an alternative choice for tonometry in patients with corneal disease or pathology.

\section{References}

1. The Advanced Glaucoma Intervention Study (AGIS): 7. The relationship between control of intraocular pressure and visual field deterioration.The AGIS Investigators. Am J Ophthalmol 2000; 130: 429-40.

2. Doherty MD, Carrim ZI, O'Neill DP. Diaton tonometry: an assessment of validity and preference against Goldmann tonometry. Clin Experiment Ophthalmol 2012; 40: e171-5.

3. Toker MI, Vural A, Erdogan H, Topalkara A, Arici MK. Central corneal thickness and Diaton transpalpebral tonometry. Graefes Arch Clin Exp Ophthalmol 2008; 246: 881-9.

4. Sandner D, Böhm A, Kostov S, Pillunat L. Measurement of the intraocular pressure with the "transpalpebral tonometer" TGDc-01 in comparison with applanation tonometry. Graefes Arch Clin Exp Ophthalmol 2005; 243: 563-9.

5. Troost A, Yun SH, Specht K, Krummenauer F, Schwenn O. Transpalpebral tonometry: reliability and comparison with Goldmann applanation tonometry and palpation in healthy volunteers. Br J Ophthalmol 2005; 89: 280-3.

6. Li Y, Shi J, Duan X, Fan F. Transpalpebral measurement of intraocular pressure using the Diaton tonometer versus standard Goldmann applanation tonometry. Graefes Arch Clin Exp Ophthalmol 2010; 248: 1765-70.

7. Doughty MJ, Zaman ML. Human corneal thickness and its impact on intraocular pressure measures: a review and meta-analysis approach. Surv Ophthalmol 2000; 44: 367-408. 